\title{
"IN THE WAKE OF HMS DRAGON"
}

\author{
CAPT (SAN) IVOR C. LITTLE
}

Much has recently been written about the South African Navy in World War 2 but comparatively little has been mentioned about South Africans serving in the Royal Navy over the same period.

Large drafts of Royal Naval Volunteer Reserve personnel were called up at the outbreak of the war to augment the peacetime crews of British warships and bring them up to their wartime manning scale. One of these groups was dispatched to West Africa to join HMS DRAGON, reputedly in her time the luckiest ship in the Royal Navy. During her career she was comparatively obscure - never doing anything of note and her fame rested entirely on her ability to never be in the wrong place at any time. She was in fact a maritime dodger, malingerer and skiver and her crew, especially the South Africans aboard, loved her for it. After her luck finally ran out and she was sunk, she became a popular ship in literature (at least three books have been written based on adventures in her) and has since emerged in reference books as a bit of a curiosity because of her original strange design.
With a resurgence in interest, spearheaded by Car Mac Bisset of the Naval Museum in Simonstown, in South Africans seconded to the Royal Navy in World War 2 she has become noted. Various articles have appeared in "Navy News" and other publications concerning veterans who served in her, so let us consider the ship in detail.

DRAGON was a DANAE class light cruiser ordered in September 1916 as an "Improved CERES class" and in response to an intelligence report, later proved false, that the Germans were planning a powerful new light cruiser class. She was one of three, her sisters being DANAE and DAUNTLESS, and these three were later followed by a second group of nine ships, making a class of 12 in all. Their design was effective but unbalanced and as completed with a large aircraft hanger under the bridge behind B gun they were well armed but ungainly looking ships.

The DRAGON was laid down by Scott and Co in January 1917 and launched on the 29th of December 1917. When completed in August 1918 she had a

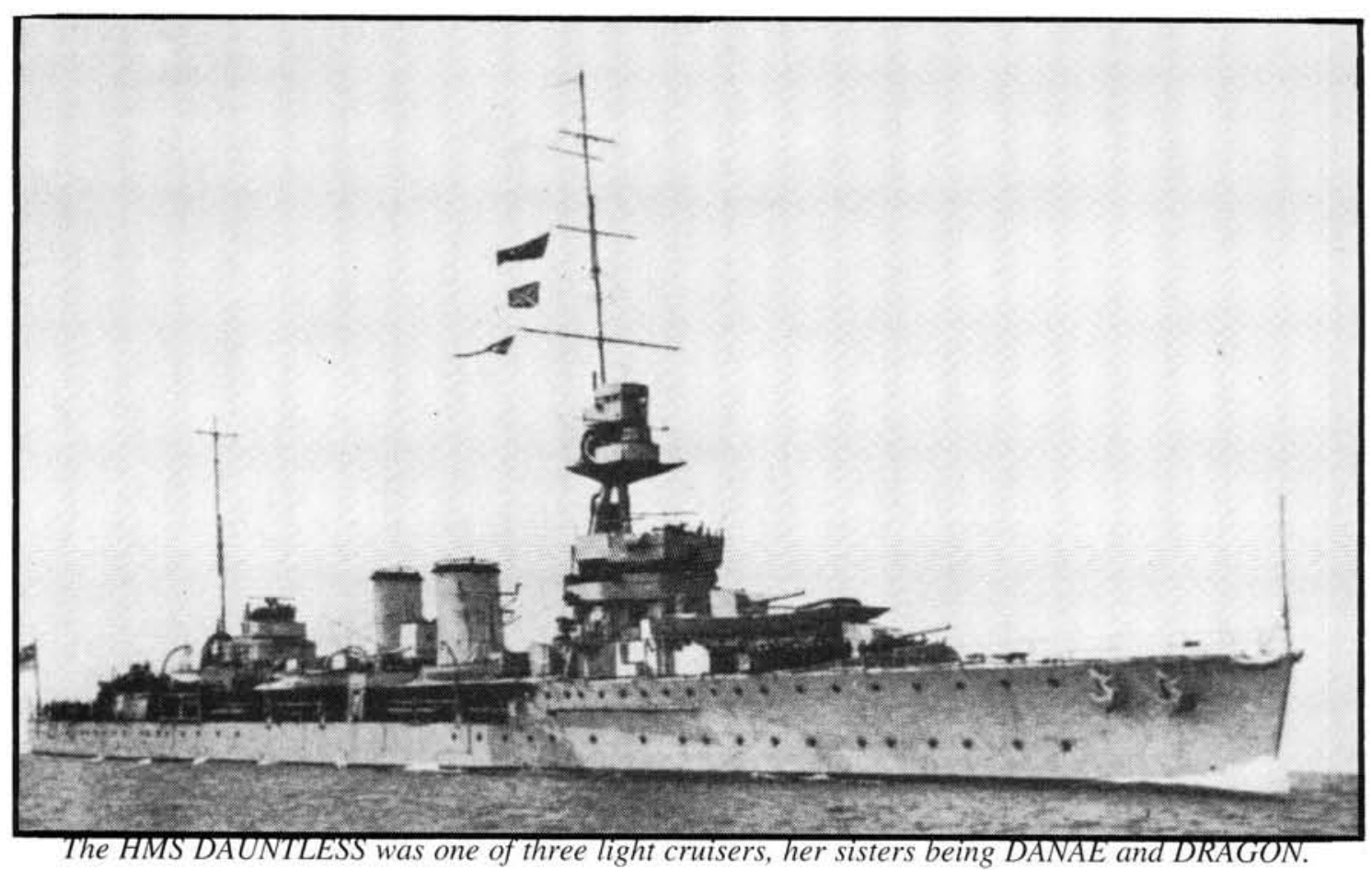


length of $142,6 \mathrm{~m}$, a beam of $13,9 \mathrm{~m}$ and draught of $5,0 \mathrm{~m}$. When fully loaded her tonnage was 5870 tons and this weight was pushed along by twin Brown-Curtis turbines which generated $40000 \mathrm{shp}$ and gave her a designed speed of 29 knots. Although lightly armoured she was by the standards of the time well armed with a main armament of six $\times 6$ inch guns. She had a wartime complement of 450 men.

On completion of her trials DRAGON was posted to the 5th Light Cruiser Squadron (LCS), Harwich Force, starting her career by arriving just in time for the end of the war. Early in 1919 she was transferred to the Baltic where once again she got in on the end of the trouble and in time to move back to the Atlantic. There she joined the peacetime navy as part of the lst Light Cruiser Squadron, Atlantic Fleet. Her main duty here was to form part of the escort for the Prince of Wales' visit to the West Indies in August 1919.

She was a happy ship and remained in the Atlantic for all of her peacetime career, changing her appearance for the better and being mainly employed on the West Indies station. During this period a young Boy Seaman by the name of Joe Almond served in her. $\mathrm{He}$ later emigrated to South Africa after the war and became chief instructor at the "General Botha" where, affectionately known as "Nuts", he was mentor to generations of South African seafarers.

Towards the end of the '30s there followed a period in reserve and then in September 1939 she was recommissioned at Chatham for war service. By this time the DRAGON was no longer quite as modern as she could be nor could she breathe the amount of fire really required, but with the motto- "We yield, but only to St George! "proudly displayed on the crest on her bridge-front she went off to war.

Her first posting was back to her old station in the Atlantic. This time not the sunny climes of the West Indies but the harsh conditions of the Greenland Gap and the Northern Atlantic. After one patrol of this nature she was relieved on station by the armed merchantman RAWALPINDI. Eight hours after the handover RAWALPINDI encountered the German pocket battleships SCHARNHORST and GNEISENAU. The RAWALPINDI, an ex $P$ and $O$ passenger liner was commanded by Captain E.C. Kennedy and manned by a crew of reservists. She was armed with eight sixinch guns and was no match for the two 2600 ton German battleships and their eleven inch guns.

Kennedy had stumbled upon a brace of tigers and immediately laid down a smoke screen and attempted to escape into a fog bank. The SCHARNHORST cut him off, signalled him to stop and put a shot across his bows. When the RAWALPINDI ignored this the SCHARNHORST fired a salvo at her. Kennedy immediately replied with a salvo of his own. The GNEISENAU now entered the action and a one- sided battle ensued where the RAWALPINDI was battered into a smoking wreck in 40 minutes. Kennedy refused to surrender and his ship sunk slowly so that 39 officers and 226 ratings went down fighting with the ship. Only 37 seamen survived, picked up by the Germans and the armed merchant cruiser CHITRAL. Kennedy was awarded a posthumous VC.

DRAGON was then switched to the Mediterranean and assigned to convoy escort duties, particularly off the Italian coast and Greek Islands. These easy assignments proved the war to be a pleasant jolly from which a ship such as DRAGON could well be spared and she was sent to the Indian Ocean. A few weeks later Italy entered the war on the side of the Axis - too late to upset the DRAGON's Mediterranean cruising but in time to enable her at long last after more than 20 years to get into action. Together with the aircraft carrier HERMES she bombarded Mogadishu in Italian Somaliland hardly a difficult assignment. This completed she went back around the Cape to West Africa to take her place in a task force occupying Dakar. Here she lived up to her fire-eating name by taking part in the sinking of a submarine and capturing the French merchant ship MENDOZA which she then escorted to Freetown in Sierra Leone. 
There she was joined by 11 South Africans, amongst them Eric Little, John van der Byl, now a leading resident of Irene in the Transvaal, Norman Macdonald of Johannesburg, S.A. Swinney of Port Elizabeth and L.R. Reader of Gilletts in Natal. After being called up they had been kitted out and transported to Freetown in the troopship STRATHMORE. There they were transferred to the depot ship EDINBURGH CASTLE to await assignment. As the weeks dragged on some of them were appointed to the Flowerclass corvette CLEMATIS (which had just been engaged in a highly successful action against a surface raider) for a spell before being returned to the EDINBURGH CASTLE and ultimately put aboard the DRAGON.

The elderly DRAGON, with her happy complement recently augmented by her Springbok contingent, then sailed for Takoradi. Her crew were supremely confident. Their successes in Dakar had resulted in them taking the full brunt of the French shore batteries fire which had accomplished no more than 37 shrapnel holes, a few slightly burned seamen and one dead canary in the seamens' mess. A short and uneventful stop in Takoradi as a convoy escort was followed by a short run on to Lagos, Nigeria. Whilst entering the harbour there in dense fog the DRAGON narrowly escaped collision with a departing ship. She also narrowly escaped being mined - the ship immediately following her into the harbour was blown up. It was here in Lagos that the DRAGON first became known for her rugby team where her South Africans contributed towards this reputation. After Lagos came Pointe- Noir and a further uneventful run South to Simonstown for dry-docking and refitting.

Here the ship was adopted by the famous Great Dane dog "Nuisance" who would come aboard every morning after the decks had been hosed down and after a morning aboard would move off to another ship. At four pm when the liberty men went ashore Nuisance would join them for an evening in the Union Jack Club, returning to Simonstown in the first train in the morn- ing. At Simonstown a further group of South Africans joined the ship as part of her engineering complement. The refit dragged on into mid-winter (although no one was complaining) until finally the elderly ship was ready for her next bout of action which came about sooner than expected.

A rough passage to Port Elizabeth to "show the flag" was cut short when the DRAGON was abruptly sailed from PE leaving 15 of her crew ashore. The Court line freighter HANNINGTON COURT had been mined and was ablaze from stem to stern whilst the Admiralty tug ST DOGMAEL attempted to tow her to safety. The weather was atrocious and although the tug got the crew off, the ship was unsalvageable and was eventually sunk by 13 shells from the DRAGON's 6 inch guns. This done the DRAGON escorted the ST DOGMAEL to Simonstown and then returned to Durban to escort a convoy to Mauritius. One of the ships in the convoy was the Bank Liner TEVIOTBANK with a full cargo of mines, This ship and DRAGON ploughed along side by side to Port Louis, the only excitement of the trip being the interception of a Vichy French convoy by the $\mathrm{RN}$ in the same vicinity. Together they pushed on to Colombo and then on to Singapore where the twosome split up. DRAGON had a new home port, in fact she was now part of the Eastern Fleet, a grand title for herself and HMS MAURITIUS lying alongside undergoing repairs.

Singapore in peacetime is an interesting place even if on this occasion it was flooded with Australian soldiers. Apart from sightseeing there were the famous nightclubs along Lavender Street including the New World Cabaret with the longest bar in the world. Tiger Beer flowed freely and all was well in the matelots world. All agreed that "war was hell" and something had to be done about it. A good solution was a rugby match and so one was organised against a newcomer. HMS DURBAN and with 10 South Africans in DRAGON's team the result of 25-6 in her favour was almost a foregone conclusion. A few days later they also defeated a New Zealand army team 8 3. This was obviously in the good old 
days of world-beating South African rugby teams!

Slowly the Eastern Fleet grew. The three cruisers already there were joined by Australian, Dutch and US ships and eventually by two large battleships HMS PRINCE OF WALES and REPULSE. There seemed to be no end to the braaivleis and sunny skies when DRAGON was despatched to sea to escort a convoy to the Bay of Bengal. There she handed her charges over to HMS EXETER and proceeded to Penang where the lotus life continued. DRAGON beat the Australian ship KINIMBLA 6-3 in a tough game of rugby and all was still well in our fighting men's world. Only the brand of beer had changed.

The announcement of a return trip to the Bay of Bengal came as an annoyance but they knew they would soon be back so who cared? Four hours after they left Penang the Japanese bombed Pearl Harbour, then Singapore and then Penang. Troops were landed in Malaya and Britain was at war with Japan. Course was immediately reversed back to Penang where the ship arrived to find an air raid in progress so off she went to Port Swettenham, arriving there also in the middle of an air raid. Two days later on December 10th 1941 both the PRINCE OF WALES and the REPULSE were sunk by a torpedo bomber attack off the Malayan coast when caught without air cover during a patrol. The war suddenly seemed very close.

The Japanese Army was pushing steadily down the length of Malaya and DRAGON was despatched to Singapore to join the newly formed ABDA squadron (Australian, British, Dutch, American). Singapore was preparing for invasion and warehouses were being emptied and the floating dock scuttled. Together with HMAS VAMPIRE, a destroyer, DRAGON was given the job of escorting a convoy laden with evacuees out into the Indian Ocean, a job she accomplished without loss. This done she returned with VAMPIRE to Padang on the west coast of Sumatra to join up with HMS DURBAN and to spend Xmas Day 1941 alongside. It was a last happy break. The Japanese in- vaded Sumatra and air raids on Singapore were a daily occurrence. The port was under threat and had to be held at all costs. DRAGON, DURBAN and VAMPIRE thus attached themselves to the Australian cruiser HOBART and two destroyers and proceeded to escort a convoy of six troopships to Singapore. Off Batavia they were joined by the Dutch cruiser SUMATRA, two more destroyers and air cover. Once again the convoy got through unscathed but this time to a blazing Singapore. The thousands of troops were put ashore to stem the Japanese advance and the warships left for Johore where, of all things, DRAGON had a game of rugby against HMS JUPITER scheduled. The game was abandoned in the second half due to Japanese air attack with the score 32 -3 in DRAGON's favour.

With the situation in Singapore deteriorating Admiral Sir Geoffrey Layton, the Commander-in-Chief Singapore, and his staff decided to move to Tanjon Priok in Batavia. The ships assigned to this first official notice of an intention to possibly surrender Singapore were DRAGON and DURBAN, who were thus recalled to Singapore. The run thereafter to Batavia was carried out at 28 knots on all six boilers, with blistering funnels and in record time. At Tanjon Priok Layton went ashore and commenced grouping the Far East Fleet. The Dutch cruiser JAVA joined, then SUMATRA, then a brace of destroyers, the Australian PERTH and finally HMS EXETER of River Plate fame.

Tanjong Priok was fairly quiet after Singapore and so DRAGON in company with JAVA, EXPRESS, ENCOUNTER and ELECTRA were despatched down to the Australian coast to rendezvous with the Australian cruiser CANBERRA and the Cunarder AQUITANIA with a load of Australian soldiers. She was safely delivered to Sumatra and the DRAGON returned to the more interesting world of Tanjong Priok, rugby (they beat DURBAN 25-0) and dancing in the evenings at the "Yin Ping" Cabaret. The Japanese had meanwhile invaded Borneo and Singapore was under siege.

Once again it was off to sea to collect a convoy. It was also once again the Indian Ocean where DRAGON, EXETER, 
GLASGOW and two Dutch destroyers gathered around five large troopships and headed in to Singapore. In the Banka Strait near Singapore they came under air attack which was beaten off by gunfire and Dutch air support. Nonetheless the attacks continued and Singapore was entered under heavy bombing with RAF and Dutch planes engaging Japanese bombers overhead. The troopers went alongside and DRAGON left for Jahore to refuel, doing the whole run under air attack but arriving unscathed. Jahore was already abandoned except for a rearguard dismantling guns, blowing up workshops and destroying machinery. Air raids were constant. Bombs landed in the water alongside, in the jetty alongside but never on DRAGON and a feeling began to grow amongst her crew that they were going to survive this war. The naval rearguard handed over to the 93rd Argyll and Sutherland Highlanders and the ships left, leaving DRAGON and SCOUT as guardships. Eventually it was time for them too to leave and with lots of cries of "good luck" the naval base was left to its army defenders.

Under continued bombing attack the two ships moved down to Singapore and started taking aboard women and children. Singapore harbour started emptying out as the last merchantmen laden with refugees started their runs for safety. Eventually at about twelve noon DRAGON cast off, took station next to the Canadian Pacific liner EMPRESS OF ASIA and then with other stragglers fought their way through to Batavia, also under air attack. DRAGON was the last warship out of Singapore before it surrendered. The attack on Batavia continued but DRAGON, ELECTRA and DURBAN were at sea almost immediately to escort the Union Castle liner WARWICK CASTLE to Australia. After continuous air attack as far as the Sunda Straits things calmed down a bit in the Indian Ocean. Three days out DRAGON handed her charges over to the CANBERRA and with DURBAN joined a 10 knot convoy consisting of nine oil tankers with the destination of Pelambang in the dangerous Banka Straits on the coast of Sumatra. To make matters worse the Japanese were landing in the vicinity. The convoy in fact reached Pelambang unobserved in the midst of a tropical rain storm. DRAGON then left DURBAN in charge and returned to Tanjong Priok. The storm cleared and DURBAN was attacked on her way back to Batavia. She was severely damaged and unable to rejoin DRAGON which was now escorting HMS DORSETSHIRE and another trooper in to the coast of Sumatra. Singapore had fallen, Sumatra was going and the next job was to evacuate Batavia.

Tanjong Priok was under heavy attack when DRAGON steamed in from Sumatra to take charge of the evacuation convoy in company with SCOUT. Everything that could float moved out through the Sunda Straits and into the Indian Ocean and safety. Despite heavy machine gunning and bombing this makeshift convoy reached safety unscathed. DRAGON and SCOUT then headed back to Batavia for the final evacuation. In the meantime the rest of the fleet was taking a pasting at the hands of the Japanese at the Battle of Bali, a battle now all but forgotten. The consequences were however that the Japanese had got ashore at Bali, held most of Malaya, Sumatra, Borneo, Bali, the Celebes and were going after Batavia and Java.

The remnants of the fleet gathered at Tanjong Priok and endured one air attack after the other. During this time a strange happening occurred, once again in the world of rugby. HMS EXETER had a rugby team that hadn' $\dagger$ been defeated in 14 games and who were mostly Welsh. DRAGON had an undefeated team which included 13 South Africans. That evening in a lull between air raids the two teams took the field for a magnificent match which ended in a 0 - 0 draw. South African Eric Little was the referee and for this received his Royal Navy rugby "blue" or "colours",

Next morning the fleet was divided into sections to sail into the Java Sea and find the Japanese fleet. DRAGON formed one section together with DANAE, HOBART and four destroyers. The section carried out a short patrol around the island of Batavia under heavy air attack and then returned to 
refuel. During this bunkering operation DRAGON received contaminated fuel mixed with salt water, probably due to sabotage. She thus delayed the sailing of the rest of her section to join the main fleet in the Java Sea until the next morning. She, HOBART, DANAE, TENEDOS and SCOUT then steamed towards their patrol station off Sumatra. The other group, commanded by Rear Admiral Karel Doorman of the Royal Dutch Navy, consisted of the two eight inch cruisers HMS EXETER and USS HOUSTON, three six inch cruisers, the Dutch DE RUYTER and JAVA and HMAS PERTH and nine destroyers of which four were American, three British and two Dutch. Doorman's objective with this fleet, known as the ABDA fleet, was to attack a large convoy approaching from Java. On 27 February 1943 he found the convoy and immediately attacked. The Japanese escorting fleet was roughly equal to the $A B D A$ fleet and consisted of two heavy cruisers, two light cruisers and fourteen destroyers.

The Japanese however had air superiority, the ships were in good repair and the men fresh. Doorman's crews by contrast were tired and nervous and his ships badly in need of overhaul. The battle, later to be know as the Battle of the Java Sea, began with a salvo of 8 inch shells fired from one of the Japanese cruisers at extreme range. HOUSTON and EXETER answered. The range closed rapidly and although the ABDA fleet drew first blood, about an hour after the action began HMS EXETER was hit by an 8 inch shell that penetrated to one of her boiler rooms and severed a main steam line without exploding. With her speed suddenly cut to seven knots she turned away from the enemy, creating considerable confusion in the ABDA battle line. The Japanese then launched a torpedo attack and one of the torpedoes broke a Dutch destroyer in half. The ABDA fleet immediately retaliated with a torpedo attack of their own which damaged two Japanese destroyers but resulted in the loss of one Allied destroyer. When night fell the Japanese fell back on to their convoy pursued by Doorman minus EXETER which was limping back to Soerabaja. He was spotted and illuminated by Japanese aircraft and shortly after midnight JAVA was torpedoed by a Japanese cruiser. Whilst swinging away DE RUYTER was also torpedoed. The two Dutch ships went down with the loss of 344 men. HOUSTON and PERTH escaped into the darkness and headed for the Sunda Strait. The following night, short of ammunition and badly in need of repairs, they came across the main Japanese invasion fleet. In the action that followed they accounted for four transports before the PERTH was stopped by a torpedo and then sunk by gunfire. The Japanese then furned their attention to the HOUSTON which went down firing. Of her crew of 1064 officers and men only 368 survived and her Captain, Albert $\mathrm{H}$ Rooks, was posthumously awarded the Congressional Medal of Honour. EXETER, escorted by HMS ENCOUNTER and USS POPE had fought her way through to Soerabaja, carried out repairs and also sailed for the Sunda Strait, separating Sumatra from Java and the only way of escape into the Indian Ocean. There the three ships were caught on a beautiful flat, calm sunny morning by four Japanese eight inch cruisers. The three smaller ABDA ships fought their way forward but by noon were sunk and their survivors taken into captivity. DRAGON thus missed by a few miles and hours the total destruction of the ABDA fleet in the Java Sea Battle. The entire fleet of 13 ships was lost, Java invaded and the Japanese gained undisputed naval supremacy in the South West Pacific. The five ships of "DRAGON's" section represented the last Allied Naval presence in the Far East and decided to run for safety after performing one last job. Zig-zagging through the islands off the West Coast of Sumatra and keeping close inshore in a tremendous tropical storm the ships escaped undetected into the Sunda Straits. There they entered the harbour of Padang in Sumatra, which was already in Japanese hands. In their haste to occupy Sumatra however, the Japanese did not have enough troops to garrison the place effectively. In this case the nearest garrison to Padang was in a town lying in a hollow a few miles away from the harbour. Entering the harbour at midnight the three cruisers lay off whilst the two destroyers went alongside and by 3 am had evacuated over a thousand civilians and Indian soldiers. One 
destroyer even had the audacity to refuel whilst lying alongside. The whole evacuation took place without a shot being fired and by dawn the whole force was on its way to Colombo.

After two days DRAGON transferred her passengers to HOBART and then retraced her steps alone back to the Sunda Straits to pick up the liner KEDAH which had broken down whilst laden with refugees. DRAGON found her, took her in tow and brought her in to Colombo without incident. There the DRAGON went into dry-dock whilst her crew were sent up into the mountains for seven days to a place called Dyalatalawa.

By Easter Sunday 1942 DRAGON was back in commission when Colombo was raided by 75 Japanese aircraft in a full scale air raid on the docks. The Japanese Navy was operating in the Bay of Bengal and they were now after the shipping in Colombo. Admiral Layton thus decided to search for and destroy the Japanese first. The DRAGON steamed hundred of miles on the fringe of the fleet during this operation, but to their horror found nothing except British survivors. What had happened was that the main fleet had in fact found the Japanese, or rather the Japanese Air force had found them. Sustained Japanese air attacks had accounted for the CORNWALL, DORSETSHIRE, HERMES, VAMPIRE and HOLLYHOCK. Amongst their crews were many dead and missing South Africans. DRAGON however returned unscathed to Colombo. There 7 young South Africans were called aft and told that they had been selected for a commission. Five were drafted to the Straits Steamer KELATAN and the remainder were put aboard the LACONIA. The stories of the latter group would be an article in itself. KELATAN did a commercial voyage in convoy via Seychelles and Mombasa to Durban but LACONIA was torpedoed NE of Ascension Island whilst laden with Italian prisoners and the two South Africans aboard found themselves prisoners in their turn of the Vichy French until released by the Americans.

DRAGON was then whilst in Colombo re-assigned to a new Eastern Fleet and was with this fleet when it entered Mombasa at the same time as the humble KELATAN. She was still the Navy's Champion rugby ship and whilst in Mombasa she defeated the garrison team 3 - 0 . The next day she sailed in company with the fleet to attack Diego Suarez in Madagascar. By now she was getting tired, as was her crew and she then returned home for a long refit in Chatham in time for Xmas 1942.

The old DRAGON was now no longer of much use to anyone and after inspection she was donated in January 1943 to the Free Polish Navy and became the CONRAD. Her career with them was very short. After a lengthy refit she arrived in the English Channel in time for D Day and distinguished herself in that invasion with the naval gunfire support she gave the British Third Division in holding a German counter attack on June 8. On the 8th of July she was torpedoed in the English Channel and scuttled as part of the new Mulberry Harbour.

And so ended a strange career. HMS DRAGON was in most major conflict areas of the sea war of World War Two, took part in major evacuations and invasions, ran hundreds of miles under aerial attack, sank a submarine and yet in her entire Royal Naval career the sum total of damage incurred in two world wars and a lengthy peacetime career was 37 shrapnel holes and a dead canary. It is no wonder her crew called her "The Luckiest Ship in the Navy" and would,like her, breathe fire in her defence. They loved her.

There were other similar ships in the Royal Navy with large South African contingents on board- the names DORSETSHIRE and NEPTUNE spring immediately to mind - whose crews were not as lucky as those in DRAGON. Hopefully one day their story will also be told.

\section{BIBLIOGRAPHY}

1. British Cruisers of World War 2 by Allen Raven and John Roverts - US Naval Institute Press.

2. The Luck of HMS DRAGON by Eric H. Little Stewart Printing Coy.

3. Reflections of a Wartime Navy Stoker by Norman Macdonald - "Home Front" Magazine Dec 87, Jan 88. 